\title{
КУЛЬТУРНА СФЕРА ТА ЕКОНОМІЧНИЙ РОЗВИТОК СУЧАСНОГО МІСТА
}

\section{CULTURAL SPHERE AND ECONOMIC DEVELOPMENT OF THE MODERN CITY}

\author{
Сирота Лілія Богданівна \\ кандидат фрілологічних наук, доцент, \\ Львівський національний університет імені Івана Франка \\ ORCID: https://orcid.org/0000-0001-7237-291X
}

Syrota Liliia

Ivan Franko Nationality University of Lviv

\begin{abstract}
У статті проаналізовано особливості розвитку культури в сучасному місті та їі роль в його економічному піднесенні. Акцентовано увагу на зміні парадигми розвитку міста в XXI ст. - від промислових до креативних. Говориться про зростання значення функцій міста, пов'язаних із рекреацією, проведенням вільного часу, культурним і науковим життям. Останні тенденції світової економіки підтверджують, що сорера культури, включаючи креативні індустрії, має значний економічний потенціал, який може позитивно вплинути на сталий розвиток міст за рахунок культурної економіки та економізації культури, а також галузевої реструктуризації та інноваційної модернізації економіки. Культурна діяльність, зорієнтована на різні верстви населення, зміцнює економічне становище міст завдяки широкому залученню населення, фрормування в нього гордості за своє рідне місто, увиразненню почуття належності до місця проживання; піднесення якості життя, збільшення кількості відвідування різних місць (культурний туризм) та залучення інвестицій, реалізації культурних проектів, розвитку галузей культури, що мають прямий вплив на економічне зростання великих населених пунктів (надання нових робочих місць, збільшення прибутків); створення позитивного іміджу та ідентичності міста.

Ключові слова: культура, економіка, креативне місто, проект, ревіталізація, кластер, міське заощадження, культура міста.
\end{abstract}

В статье проанализированы особенности развития культуры в современном городе и её роль в его экономическом подъеме. Акцентировано внимание на изменении парадигмы развития города в XXI в. - от промышленного до креативного. Говорится о росте значения функций города, связанных с рекреацией, проведением свободного времени, культурной и научной жизнью. Последние тенденции мировой экономики подтверждают, что сфера культуры, включая креативные индустрии, имеет значительный экономический потенциал, который может положительно повлиять на устойчивое развитие городов за счет культурной экономики и экономизации культуры, а также отраслевой реструктуризации и инновационной модернизации экономики. Культурная деятельность, ориентированная на различные слои населения, укрепляет экономическое положение городов благодаря широкому привлечению населения, фрормированию у него чувства гордости, принадлежности к месту жительства; повышению качества жизни, посещению различных мест (культурный туризм) и привлечению инвестиций, реализации культурных проектов, развитию отраслей культуры, имеющих прямое влияние на экономический рост города (предоставление новых рабочих мест, увеличение доходов), созданию привлекательного имиджа и идентичности города.

Ключевые слова: культура, экономика, креативный город, проект, ревитализация, кластер, городская экономия, культура города.

Modern cities face with numerous environmental, social and economic problems. There is competition between companies and states, regions and cities that strive to innovation, attracting new human resources. The potential of the creative cultural sector is increasingly taken into account. The relevance of the study is to identify culture as extremely important sphere for strengthening the economic position of the city. Modern culture seeks independent development, as its importance is due to the decisive influence on the intellectual and creative potential of society, the formation of the culture of the city and its economy. The purpose of the article will be to understand the features of a modern creative city and identify its catalysts (clusters, cultural projects, creative groups, etc.), which help to overcome economic backwardness and turn culture and the city into promising districts. The research methodology is based on the application of general scientific and special methods of cognition, in particular analysis, comparison, 
logical method, method of systematization, modeling of research data. Research results. Today, the economy and culture are closely linked. Values, beliefs and cultural achievements significantly affect the economic situation of cities. The cultural sphere contributes to urban savings. Such components of culture as event business, cultural projects, revitalization, competitions, statuses, etc. significantly affect economic growth. Today, the economy and culture are two intersecting circles, and at the center of these circles is a creative and enterprising person. It has a positive effect on beliefs that contribute to the free market and improve the institutional structure. The constituent elements of culture change with the development of cities and penetrate deeper into economic processes. It is important for the full and large-scale development of culture to understand its importance at the level of urban policy, which would provide for maximum use of local potential, compliance with European values. It is this understanding of culture that will contribute to its impact on economic performance. The practical value of the article is that the results can be used to study the role of the cultural sphere in the economic stabilization of not only some cities but also regions and states.

Keywords: culture, economy, creative city, project, revitalization, cluster, urban savings, city culture.

Постановка проблеми. Швидкий розвиток транспорту та інтернету призвів до того, що все більше людей намагається працювати дистанційно, наприклад, вдома, без необхідності не їздять до місця праці. Деякі компанії переводять свою діяльність 3 центральних частин міста у дешевші передмістя. Ці та інші зміни у функціонуванні сучасних міст, розвиток яких тісно пов'язаний зі сфрерами економіки, містобудування, архітектури, історії, соціології, географії, демографрії, статистики, психології та антропології, особливо помітні в останні десятиліття.

Сьогодні чітко спостерігаються новації у розвитку міста - від моделі міської торгівлі надлишковими товарами до моделі промислового міста, а далі до постіндустріальних та креативних міст. Великого значення набувають функкції міста, що пов'язані з відпочинком, проведенням вільного часу, культурними та науковими інтересами людини. Типовими ознаками швидкого розвитку міста стали високий ступінь зайнятості населення, існування зовнішніх і внутрішніх стимулів для розвитку, виокремлення міських переваг (якість та унікальність послуг) та людський капітал.

Нові тенденції в світовій економіці засвідчили, що сфрера культури, включаючи креативні індустрії, має значний економічний потенціал, який може позитивно вплинути на розвиток міст, сприяти подоланню численних екологічних, соціальних, економічних проблем. Сьогодні ведеться конкурентна боротьба між компаніями та державами, регіонами та містами, які прагнуть до інновацій, залучення нових людських ресурсів. Чи не тому все частіше враховується потенціал креативного сектору.

Аналіз останніх досліджень і публікацій. Сучасні дослідження доводять, що культурна діяльність сприяє розвитку міст, оскільки передбачає: формування відчутя соціальної єдності, національної ідентичності; високу якість життя; розвиток сорери дозвілля та інвестування; реалізацію різних культурних проектів; розви- ток таких галузей культури, які можуть суттєво покращити економічне становище; створення привабливого образу міста [3; 18; 21; 24].

Українські дослідники Н. Карасьова [6], С. Киризюк [7] В. Мазуренко [9] та ін. аналізують особливості інноваційно-креативного розвитку сучасної цивілізації, яку вважають альтернативою до постіндустріального суспільства. За кордоном значна увага приділяється проблемам розвитку такого типу економіки, як креативна, окреслена роль культури і творчості для економіки, активно аналізується динаміка культурного простору, залежність економіки від креативних професій, механізми фрінансування креативних індустрій та інше (Р. Флоріда [22], Дж. Фурд [25], Дж. Ховкінс [26], Дж. Ньюбайгін [28]).

Виділення невирішених раніше частин загальної проблеми. Постійні зміни в культурі та економіці спонукають вчених всебічно досліджувати дані проблеми. Аналіз доробку вище зазначених дослідників свідчить, що проблема взаємовідносин культури й економіки надзвичайно важлива. Недостатньо висвітленими залишаються питання ролі культурної ссрери в економічному зростанні міст.

Формулювання цілей статті. Метою дослідження $€$ аналіз особливостей розвитку сучасної культурної сорери та її вплив і значення для сталої економіки міста.

Виклад основного матеріалу дослідження. Наголосимо, що сьогодні часто говориться про інноваційний розвиток міст, зокрема не лише кількісний (для прикладу, зростання валового внутрішнього продукту, пов'язаного 3 виробництвом товарів та послуг), але і якісний, спрямований на задоволення економічних, соціальних і культурних потреб людей. Відтак часто наголошується на важливості покращення їх якості життя. Щоб це швидше відбулося, фрормуються концепції сталого розвитку населених пунктів, відбувається активне включення культурної сфери у політику сталого розвитку суспільства [20, с. 7-38]. 
Окрім незаперечного, широко визнаного значення культури для розвитку суспільства, акцентується увага на значній подібності культурного та природного (біосорерного) капіталу. Стан сучасного природного та культурного капіталу залежить від минулих здобутків. Вони обидва важливі для повноцінного сучасного економічного розвитку. Культурний капітал (для прикладу, це різні компетенції людини, а також такі об'єкти, як: книги, картини, скульптури та ін.) в економічному та соціальному розвитку важливий, що є додатковим аргументом до розуміння культури як ресурсу сталого розвитку [2].

Міська політика у сфері культури. Одними із завдань міськвиконкомів $€$ турбота про культуру в місті, зокрема підтримка та сприяння творчості, діяльності культурних інституцій, піклування про пам'ятки культури. Оскільки в Україні більшість державних закладів культури (бібліотеки, громадські центри, театри, галереї тощо) підпорядковуються місцевим органам влади, тому їх засновником та інвестором є саме ці органи. Крім державних, приватні організації також можуть розраховувати на допомогу з боку міста, зокрема подавати заявки на фрінансову підтримку (гранти, конкурси). Окрім непрямого впливу на сфреру культури (сприяння у налагодженні міжнародних контактів, підтримка освіти, видання розпоряджень), міська влада може мати прямий вплив на культурну діяльність через фрінансування установ чи окремих їх заходів.

Політика міста у сорері культури може здійснюватися у двох взаємозалежних напрямках - розвиток культурної інфрраструктури та різних галузей культури. Міська політика у сорері культури, як правило, спрямована на створення нових ресурсів, підвищення ефективності управління цими ресурсами, а також на активізацію, адаптацію до нових потреб. Місто у своєму розпорядженні має матеріальний та нематеріальний культурний ресурс. Що стосується суто економічного виміру, то всебічне використання культурного капіталу можливе насамперед через розвиток різних галузей культури, що дає змогу створити нові робочі місця, збільшити дохід міста та розширити експорт продукції. Нематеріальний ресурс вирішальний у фрормуванні привабливого образу міста. Від духовної активності містян залежить якість життя в місті, рівень доступу до загальнонаціональних надбань, особливість культурних проектів, туристична активність, співпраця з інвесторами тощо.
Культура міста в XXI ст. Джон Монтгомері, керівник лондонської консалтингової фрірми «Urban Culturs LtD», зазначав, що в XXI ст. міста ввійшли у нову, п'яту фразу розвитку, на якій доступна і зрозуміла широким верствам культура може відігравати важливу роль у конкурентоспроможності великих населених пунктів. Цей етап тісно пов'язаний з активним розвитком нових фрорм художньої виразності та дозвілля (особливо з комп'ютерною індустрією, циорровими медіа та Інтернетом). Крім того, в передових західних суспільствах з'явилася нова тенденція, де, крім задоволення таких потреб людини, як наявність побутової техніки, телевізора, домашнього кінотеатру, ноутбука та мобільного телефрону, виникають ще інші потреби, спрямовані на вираження своєї неповторності (для прикладу, шляхом придбання рідкісних видань, оригінальних творів мистецтва та предметів розкоші). Тому попит на мистецтво, дизайн та індивідуально підібрану або «на замовлення» продукцію зростає у світі. Інноваційні виробнича продукція, мода, компетентність у дизайні та мистецтві набувають все більшого значення [27].

Сьогодні найкраще розвиваються міста, в яких існують кластери технологічно розвинених, спеціалізованих галузей, що легко реагують на зміни. $€$ прогнози, що у XXI ст. домінуватимуть ті міста, економіка яких базуватиметься на цисрровій індустрії, економіці знань та креативних галузях, а також ті, в яких розвиватиметься художня творчість та дизайн. Баланс між креативною та динамічною економікою, інноваційною культурною діяльністю і добре узгодженою ії̈ матеріальною фрормою, в якій відбувається ця діяльність та фуннкціонує економіка, буде вирішальним для успіху міста. Ці три показники міської динаміки постійно змінюються та узгоджуються. Їх рівновагу порушує швидкий технологічний розвиток, тому роль управління полягає в її утриманні [1].

Нова концепція міста. Концепція креативного міста акцентує на ролі культурних галузей, культурної інфраструктури в житті суспільства, значенні «креативної верстви». Креативність означає, що місто не тільки здатне продукувати конкурентоспроможні товари, але може швидко змінюватися та адаптуватися відповідно до вимог конкуренції та попиту. Завдяки своїм культурним ресурсам воно може залучати інвестиції в різні галузі економіки та творчі організації [4; 23]. 3a словами професора Бруклін-коледжу і Міського університету в Нью-Йорку Шарон Зукін, креативне місто сприяє виявам творчості і 
новаторству за допомогою заохочення різних пропозицій та встановлення низьких бар'єрів для їх реалізації. Іншими словами, креативне місто створює сприятливі умови для ринкових відносин та успішного початку проектів [5; 31].

Сучасні виклики, і перш за все міграційні процеси та культури різних народів і країн, зумовили виникнення поняття міжкультурного міста - міста, у якому проживають люди різної етнічної, національної приналежності, релігійного віросповідання. Ця різноманітність позитивно сприймається міським урядом, засобами масової інорормації, містянами як ресурс, в якому завдяки зіткненню різних культур спостерігається ефрект синергії, тобто під час взаємодії двох або більше фракторів їхня дія значно більша від ефекту, який може дати сума окремих компонентів) [11]. Міжкультурне місто використовує це розмаїття як джерело динаміки, інновацій, креативності та економічного зростання. Завдяки ефективній міській політиці представники різних національностей чи різних віросповідань можуть зустрітися та налагодити співпрацю. Таке місто може легко адаптуватися до змін в політиці та економіці.

Кластери та креативні індустрії. Сучасний суспільний розвиток свідчить, що міста ніколи не втратять свого значення. Наукові дослідження профресора Гарвардської бізнес-школи Майкла Портера доводять роль міст в інсрормаційному суспільстві. За словами цього вченого, найважливішим у сучасній економіці $\epsilon$ правильне розміщення економічної діяльності. Зазвичай конкурентна перевага досягається у певних галузях або у взаємопов'язаних галузях. Таким чином фрормуються певні кластери (компанії, пов'язані між собою здатністю надавати окремі послуги та обмінюватися товарами; компанії, що працюють у суміжних секторах; установи, що співпрацюють з ними), які завдяки тісним зв'язкам та близькому розташуванню їх складових створюють, з одного боку, зручну мережу для співпраці, а з іншого, - для конкуренції. Кластерам, які досягли критичного рівня розвитку, здобули конкурентний успіх, властива більш сильна регіональна чи локальна (великих міст) економіка. Вони перш за все фрормуються на основі інноваційних і використовуючих новітні технології компаній. В їхньому середовищі достатньо місця і для сорери культури [14].

У кластерах створюється мережа компаній, які міцно зінтегровані між собою; фрормується взаємозв'язана продукція [15]. Ці процеси спричинюють виникнення нових видів бізнесу, активізують підприємництво та притягують творчих людей. Оскільки кластери часто є центрами інновацій та творчості, вони важливі для майбутнього розвитку міст.

«Креативний клас». Сучасні дослідження свідчать, що висококвалісріковані фрахівці навряд чи захочуть змінювати постійне місце проживання заради збереження місця праці. Якщо вони будуть все ж таки змінювати своє мешкання, то керуватимуться, найперше, специфрікою певного міста та якістю життя у ньому. Тому різні компанії намагаються розмістити свої офріси в перспективних місцях, щоб задовільнити потреби творчих та освічених працівників. Американський економіст, соціолог і автор теорії креативного класу Річард Флорида створив теорію творчого капіталу, засновану на переконанні, що основою будь-якого розвитку $\epsilon$ креативні люди, які обирають такі місця для свого проживання, що характеризуються інноваціями, різноманітністю та толерантністю. Вони створюють Т. зв. креативний клас, що визначається як економічний клас, який складається 3 людей, які розвивають економіку своєю творчістю; виконують роботу, результатом якої $\epsilon$ створення якісно нової та змістовної продукції. Основою цього класу є вчені, інженери, співаки, актори, дизайнери, архітектори, письменники, видавці, громадські діячі, викладачі, аналітики та ін. [22, с. 22-23]. Р. Флоріда називає їх також надкреативною групою, оскільки вони володіють передовими знаннями (наприклад, високими технологіями, надають фрінансові послуги, займаються охороною здоров'я, управлінням бізнесу) і від яких вимагається незалежне інноваційне мислення [22, с. 23-24]. Тому вчений припускає, що запорукою успіху міст є створення зручностей, зокрема культурно і рекреаційно привабливого способу життя, який би задовільнив вимоги креативного класу.

Залучення до міста креативного класу - це ключове питання на рівні «бути чи не бути». Креативні (інтелектуальні) люди, що вибрали те чи інше місто для свого постійного проживання і праці, притягнуть за собою певні компанії (чи інвестиції) , які намагатимуться використати цей креативний ресурс [22].

Привабливий образ міста - мета івентбізнесу. Сучасні міста прагнуть бути винятковими і на цій основі розвивати свої конкурентні переваги. Основою оригінальності, безумовно, є ендогенні ресурси (наприклад, культурна спадщина (матеріальна і нематеріальна), населення (людський капітал), задатки і здібності людини). Багато 3 цих ресурсів можна широко розвивати та рекламувати. Зокрема і за допомогою різних івентів, які відносяться до ссрери культури. Їх харак- 
терною ознакою $€$ структурність (зазвичай вони складаються 3 різних видів діяльності), обмеженість у часі і місці, наявність таких складових, як святкування / свято, публічність та групи зацікавлених сторін. $€$ такі міста, які створюють свій імідж як місця цікавих та різноманітних подій (для прикладу, австралійський Мельбурн просуває себе як «місто світових подій», а Гонконг прагне стати одним 3 «міст найкращих у світі подій»).

Події, які часто використовуються у промоції міста, - це здебільшого фестивалі. Згадаємо Единбург як «головне фрестивальне місто у світі». Івенти зміцнюють імідж міста, посилюють активність міському простору, фрормують у містян почуття гордості за своє місто. Вони також можуть бути важливою складовою економіки міста.

Слід розрізняти поняття «містом $з$ подіями» i «місто подій». Отримати останній титул прагне багато міст, які організовують різні заходи. «Місто подій» більш активне щодо створення нових івентів, а не просто приймає та підтримує зовнішні проекти. Уряд такого міста схильний трактувати події як складову міської політики, промоції міста за його межами та спосіб досягнення високої якості життя та високого рівня його розвитку [29, р. 23].

Просресори Університету Тілбурга Грег Річардс і Роберт Палмер пропонують міським урядам, які прагнуть фрормувати свою стратегію на визнанні ролі івентів, створили ціле портороліо малих і масштабних заходів. Завдяки таким стратегіям міста відчують фрінансовіі, соціальні та культурні переваги певних подій.

Важливо, щоб події бути міно прив'язані до специфріки місцевого контексту. Натомість події, організовані за принципом «купи - продай 3 іншого міста» мають мало шансів на успіх. Міські події можуть бути створені за рахунок місцевих ендогенних ресурсів. Інколи вони можуть фрормувати свої культурні стратегії на основі подій, що змінюють місце проведення. I це не заважає містам змагатися за титул головного організатора визначної події. Для прикладу, такої, як Всесвітня виставка ЕХРО, спортивні олімпіади та ін. Саме такі події сьогодні стимулюють процес ревіталізації міста [19].

Міські стратегії розвитку на початку XXI ст. стали більш досконалими: все частіше акцентується не лише на важливості корегування іміджу міста чи навіть його економічного розвитку, а й на значимості «м'яких» результатів. Можна навіть говорити про суспільну ревіталізацію, тобто таку, що зосереджується на покращенні якості життя, а не лише на підтримці бізнесу та залученні інвесторів. Другою важливою зміною у розумінні ролі івентів $€$ висунення ідей, зорієнтованих на довгострокові результати. Важливо заздалегідь спланувати, як зберегти «доробок» заходу, його позитивний вплив на місто та підтримку цього впливу.

Міські заощадження - символічні. Останнім часом поняття «культура» набуло нового, інструментального значення: культура - це сукупність ідей, видів діяльності, місць та символів, які разом створюють т. зв. міську економію (заощадження) ресурсів [12]. Такі цінності, як доброзичлива чи святкова атмосфрера міста, почуття приналежності до події чи отриманий досвід учасників заходу, є складовими «економії відчуттів / переживань».

На думку викладачів Каліфрорнійського університету в Лос-Анджелесі Б. Джозесра Пайна II та Інституту організаційного менеджменту при Торговельній палаті США Джеймса Х. Гілмора, окрім ресурсів, товарів та послуг, досвід $є$ четвертою важливою складовою сучасної економіки. Важливо не лише набути досвіду у ссрері розваг, а й вміло увести клієнта / учасника в особливу атмосореру [13, с. 13-14]. Унікальність це те, що відрізняє досвід від звичайного обслуговування, і саме до унікального сьогодні прагне багато людей. Як правило, учасники культурних подій приїжджають до міста не лише заради місця проведення івенту, а через особливу атмоссреру та відчуття спільності з іншими відвідувачами заходу. Попит на події - це велика перспектива для міст, які розвиваються на культурних ресурсах. Як і інші суспільні блага, уряд міста може підтримувати креативну економіку (для прикладу, шляхом надання комунальної інсрраструктури та грантів для творців/виробників товарів). Через високу інвестиційну та фрінансову привабливість подій дедалі частіше ними опікуються приватні структури. Державна зі свого боку повинна запобігати домінуванню одного з цих заходів у країні чи місті.

Ревіталізація міста. Завдяки широкому розумінню ролі культури у сучасному суспільстві (створення нових робочих місць, стимулювання туристичної та інвестиційної діяльності, фрормування фрілософрії забудови міста тощо) вона все частіше стає важливою складовою міських програм активізації, тобто привернення мешканців до активного життя. Процес ревіталізації у ссрері культури здебільшого добре адаптований до певної території, її історії та мешканців.

Провідний британський урбаніст і культуролог Чарльз Лендрі [8, с. 28-35] створив типологію «культурних ревіталізаторів». Найбільш 
типовим ревіталізатором, на його думку, $\epsilon$ новий об'єкт (будівля або інноваційний проект), пристосований до особливостей культурного простору (переважно сучасного мистецтва або так званої альтернативної культури). Яскравим прикладом $€$ музей Більбао [17]. Багато міст безуспішно намагалися наслідувати приклад Більбао. Причиною їх невдач, як правило, став занадто формальний підхід: «ми побудуємо музей сучасного мистецтва, і він буде працювати», «ми запросимо відомого архітектора для його створення і музей стане відомим». У Більбао, крім довгострокового стратегічного плану, що передбачав створення комплексу різних об'єктів та районів, важливу роль відіграли відомі «бренди» Фундація Гуггенхайма та Френка О. Гері.

Дуже часто події можуть мати невдале інвестування, супроводжуватися недешевими послугами. Викладач Університету Вестмінстера в Лондоні Ендрю Сміт називає такі заходи білими слонами і стверджує, що бувають ситуації, коли міста франатично змагаються за певний титул чи право бути організатором заходу, намагаються перевершити своїх конкурентів ще більшими інвестиціями, які ніколи повністю не будуть використані і не окупляться [30]. Проблемою також можуть бути розбіжності між даною інвестицією, об'єктом інвестування та місцевою громадою. 3 одного боку, в рамках подальшого використання об'єкта інвестори намагатимуться повернути вкладені гроші за рахунок цін на квитки, які будуть занадто високими для середньостатистичного мешканця. 3 іншого боку, з'являється проблема формування іміджу: нові проекти часто $€$ передовими, гордістю міста і просуваються як престижні та елітні, тоді як місцеве населення не користується ним.

Мистецька діяльність може бути ефективним «ревіталізатором». На прикладі Фабрики заварного крему в Бірмінгемі можна побачити, як групи фрахівців завдяки своїй діяльності можуть вплинути на зміну сприйняття певної території і поступово перетворити ії̈, наприклад, в модний креативний район. Ризик у такій ревіталізації може виникнути тоді, коли існуватиме високий ступінь гентрифрікації: митці орієнтуються на більш дешевші і «автентичні», менш популярні і комерційні об'єкти. Це $€$ важливою проблемою процесу ревіталізації, адже спостерігається орієнтація діяльності та художньої продукції на задоволення смаків пересічних користувачів, а отже, витіснення елітного мистецтва більш простим, орієнтованим на масову аудиторію мистецтвом. щоб цього сталося, для прикладу, уряд міста Дубліна передбачив таку проблему та підписав довгострокову оренду приміщень за вигідними для митців цінами, щоб забезпечити їх присутність у ревіталізованому районі Темпл-Бар. Культурна й економічна значимість такого району, як Темпл-Бар, полягає в його креативності та унікальності. Отримання прибутків не головний показник в оцінці фрункціонування цієї частини Дубліна.

Окрім окремих районів, деякі особистості також можуть відіграти значну ревіталізаційну роль. До них можна віднести відомі історичні постаті (також героїв літературних творів), з якими пов'язаний розвиток культурного туризму. Прикладом може бути місто Стреторорд, яке є батьківщиною У. Шекспіра. Його культурний й економічний розвиток пов'язаний з цим світовим ім'ям. Доказом важливості культурної ссрери є зусилля бібліофріла Річарда Бута в Хей-он-Уай (Велика Британія), який перетворив маленьке містечко на світовий центр вживаних книжок. Окрім того, в Хейон-Уай проводиться щорічний «Фестиваль літератури та мистецтв», під час кого відбуваються прем'єри фрільмів, концерти. Щороку наприкінці травня туди приїжджає майже 100000 письменників, видавців і прихильників літератури. Білл Клінтон у 2001 році назвав цю подію «Вудстоком для розуму» Обидва приклади свідчать, який внесок може зробити творча та підприємлива людина (сучасна чи історична) для розвитку міста [10].

Загалом, культурні заходи відіграють значну роль у процесі ревіталізації міста. Як правило, вони є частиною авангардних проектів, які можуть суттєво прискорити економічні зміни, розширити сореру застосування культурних надбань. Правильно проведені івентпроекти мають шанс наростити соціальний капітал у певному місці. Вони стають засобом формування місцевої ідентичності, почуття приналежності до певної території, а також заангажованості та соціальної відповідальності. Залежно від специсріки та способу організації події можуть також впливати на спосіб життя та мати просвітнє значення. Зважаючи на високий рівень інвестицій в інфрраструктуру чи у ссреру збереження культурної спадщини, події часто розглядаються як важлива складова стратегії розвитку міста, оскільки спрямовані на створення особливої атмоссрери та розваг, сприяють активній участі мешканців в житті міста та відчуттю ними власної свободи.

Сучасні міста змагаються за створення та підтримку неповторного іміджу, завдяки якому 
вони виділятимуться серед інших, тобто перетворяться на привабливе місце для гостей, нових постійних мешканців та інвесторів. Парадоксально, що реалізуючи свої проекти, міста можуть бути дуже схожими одне на одного, особливо якщо їх пріоритетом $€$ глобальне розв'язання проблем, залучення митців із світовим іменем, а не локальні рішення і менш знамениті особистості, які могли б краще допомогти виокремити специфіку даної території і її населення.

Статус Європейської столиці культури як каталізатор розвитку міста. Розглядаючи вплив культури на розвиток міста, не варто ігнорувати досвідом набуття містом статусу Європейської столиці культури (далі - ЄСК). На цей титул, який присвоюється терміном на один рік, можуть претендувати міста 3 Європейського Союзу (далі - ЄС). Він присуджується тим містам, які запропонували найкращі програми культурного розвитку на один рік (з урахуванням європейських пріоритетів, широкого залучення місцевих жителів, довгострокового бачення ролі культури в місті).

Ідея європейської столиці культури виникла у 1985 році з ініціативи грецького міністра культури Меліни Меркурі. Спочатку цей проект під назвою Європейське місто культури мав за мету зблизити мешканців різних країн та сприяти їх співпраці. На конкурс подавалися проекти, які стосувалися сучасної культури та історичної спадщини, а також культурних та мистецьких досягнень інших народів, які проживають в них чи їх спадщина зберігається в цих містах.

Підставою для отримання містом статусу ЄСК стало проведення масштабних щорічних та багатопрофрільних культурних фрестивалів в Афрінах (1985), Флоренції (1986), Амстердамі (1987), Берліні (1988), Парижі (1989). Переломним моментом у концепції ЄСК став 1990 р., коли цей титул отримало м. Глазго в Шотландії. Вперше цей статус було присвоєно місту, не пов'язаному з культурою, але яке перетворило цю сореру на пріоритет свого стратегічного розвитку. Від 1990 р. вимоги щодо отримання статусу ЄСК змінювалися. Зокрема значна увага приділялася не лише масштабним культурним заходам, а й невеликим подіям за участю місцевих жителів, довготерміновим ініціативам, спрямованим на зміну іміджу міста та покращення якості життя ньому. У 1999 році з'явилася назва «Європейська столиця культури». Сьогодні діє Рішення № 445/2014/Євросоюз Європейського Парламенту і Ради від 16 квітня 2014 року, що запо- чатковує діяльність ЄС щодо Європейських культурних столиць на період 2020-2033 рр., яке, серед іншого, деталізовано розкриває критерії отримання статусу ЄКС [16, с. 37-38]. Культурний розвиток ЄКС повинен враховувати загальноєвропейські пріоритети (міжнародну співпрацю та розвиток в контексті європейської культури та історії) і базуватися на широкому залученні мешканців, організацій та муніципальних установ до підготовки та реалізації ідей ЄС.

Важливим результатом отримання статусу ЄCK стало покращення якості життя завдяки більш активному використанню культурної спадщини та міської архітектури. У період «володіння» титулом ЄСК в містах здебільшого реалізуються інфраструктурні та інвестиційні проекти (наприклад, оновлення історичної частини міста в Сібіу (ЄСК, 2007), будівництво культурного центру Кунстхаус в Граці (ЄСК, 2003), переобладнаний в культурний центр залізничний вокзал Сен-Совьйор в Ліллі (ЄСК, 2004), перетворення старих будівель трансорорматорних станцій у Кошицях (ЄСК, 2013) в сучасні центри для зустрічей та культурних заходів місцевої громади; волонтерська програма Ліверпуля (ЄСК, 2008), яка сприяла максимальному долученню мешканців до подій у місті, а також проведенню численних тренінгів та семінарів).

Проект ЄСК став одним із найбільш популярних і затребуваних проектів ЄС у сорері культури. Це єдиний проект, який безпосередньо стосується урбанізації та розширення культурного потенціалу. Для міст, які претендують на звання ЄСК, цей конкурс насамперед є чудовою можливістю переосмислити та переглянути, часто вперше, роль культури в своєму місті. Це звання присуджується не за те, яким є місто на даний момент, а за те, яким воно хотіло б стати через кілька років. Перемога у цьому конкурсі не передбачає значної фрінансової підтримки з боку ЄС: нагорода імені Меліни Меркурі становить 1,5 млн. євро, a середній бюджет міста, яке стало ЄСK, повинен бути е менше 40 млн. євро. Містові доводиться самостійно шукати кошти на реалізацію проектів. Тому перемога у конкурсі - це скоріше ще один стимул змінити своє місто, ефективніше залучати інвестиції для його розвитку. Якби не конкурс, можливо, певні культурні й економічні зміни ніколи б не відбулися у місті, оскільки воно не мало б поштовху до оновлення.

Висновки. У сучасній науці спостерігається зміна підходів до розуміння значення 
культури наприкінці XX ст. - на початку XXI ст. та однозначне визнання її економічних фрункцій (Ш. Зукін, Ч. Лендрі, Е. Сміт та ін.). Нове бачення ролі культури сорормувалося на основі осмислення змін і способів сприйняття та використання культурного потенціалу у сучасному світі. Широке розуміння культури стало не лише частиною маркетингових стратегій міста, але також невід'ємною складовою програм суспільного розвитку загалом. Культура і особливо креативні індустрії сьогодні сприймаються як ефективний механізм економічного поступу, а також як можливість підвищення якості життя в місті та вирішення різних соціальних проблем. Результатом поцінування культури, всебічного використання ії можливостей став перехід міста до вищого рівня розвитку, зокрема його суттєве економічне зростання. Водночас існують загрози звуження ролі культури, особливо під час утилітарного сприймання духовної творчості, низькому рівні підтримки таких інновацій, як альтернативне мистецтво. Незважаючи на це, всебічний розвиток культури і широке використання ії потенціалу стало невід'ємною складовою сталого розвитку сучасних міст.

\section{СПИСОК ВИКОРИСТАНИХ ДЖЕРЕЛ:}

1. Бойко-Бойчук О. В. Світові тенденції розвитку міст: міжнародний досвід. URL: http://academy.gov.ua/ej/ ej6/txts/07bovmmd.htm (дата звернення: 10.12.2020).

2. Бурдье П. Формы капитала. Экономическая социология. 2002. T. 3(5). С. 60-74. URL: www.ecsoc.msses.ru (дата звернення: 05.01.2021).

3. Давимука С. А., Федулова Л. І. Креативний сектор економіки: досвід та напрями розбудови : монографія. Львів, 2017. 528 с.

4. Жук Ю. І. Креативне місто: концепція та перспективи її впровадження в малих містах Львівської області. Охорона довкілля : зб. наук. статей XI Всеукраїнських наукових Таліївських читань. Харків: Харківський національний університет імені В. Н. Каразіна, 2015. С. 29 - а 35. URL: https://www.researchgate.net/ publication/312627732_Kreativne_misto_Koncepcia_ta_perspektivi_ii_vprovadzenna_v_malih_mistah_Lvivskoi_ oblasti (дата звернення: 28.10.2020).

5. Зукин Ш. Культура городов. URL: https://readli.net/chitat-online/?b=1012769\&pg=1 (дата звернення: 18.12.2020).

6. Карасьова Н. А. Досвід розвинених країн у сорері креативної економіки. Бізнес Інфоорм. 2019. № 10. С. $30-37$. URL: https://www.business-inform.net/article/?year=2019\&abstract=2019_10_0_30_37 (дата звернення: 29.01.2021).

7. Киризюк С. В. Міжнародні та вітчизняні тенденції розвитку креативної економіки. Науковий вісник Херсонського державного університету. Економічні науки. Херсон, 2014. Вип. 6(1). С. 68-72.

8. Лэндри Ч. Креативный город / пер. с англ. В. Гнедовский, М. Хрусталева. Москва : Классика - XXI, 2006. 399 с.

9. Мазуренко В. П., Копійка Д. В. Національні та глобальні виміри розвитку креативної економіки. Молодий вчений. 2018. № 8. С. 200-205.

10. Місто книг. URL: https://studway.com.ua/misto-knig/ (дата звернення: 27.02.2021).

11. Можейко В. Город. Спонтанность креативных пространств. Белорусские новости = Naviny.by. URL: https://naviny.online/article/20180202/1517552298-vadim-mozheyko-gorod-spontannost-kreativnyh-prostranstv (дата звернення: 23.02.2021).

12. Онлайн-дискуссия «Городская экономия и оптимизация: как большие данные сохраняют ресурсы». URL: https://archsovet.msk.ru/article/sobytiya/onlayn-diskussiya-gorodskaya-ekonomiya-i-optimizaciya-kak-bol-shiedannye-sohranyayut-resursy (дата звернення: 19.02.2021).

13. Пайн Б. Дж., Гилмор Дж. Х. Экономика впечатлений. Работа - это театр, а каждый бизнес - сцена. Москва : Вильямс, 2005. 441 с.

14. Портер М. Международная конкуренция. Конкурентные преимущества стран. Москва : Альпина Диджитал, 1990. 84 с.

15. Приклади й результати впровадження інновацій у містах світу: частина 1 / підготував Данило Ожго. URL: http://reformcenter.org.ua/innovations1 (дата звернення: 17.01.2021).

16. Рефреративний огляд європейського права (травень-червень 2014 р.) : інсрормаційно-аналітичний дайджест / за заг. ред. В. О. Зайчука. Київ : Інститут законодавства Верховної Ради України, 2014. 58 с. URL: http://instzak.rada.gov.ua/uploads/documents/31308.pdf (дата звернення: 01.02.2021).

17. Ричка Ю. Більбао. Музей Гуггенхайма. Як сучасне мистецтво врятувало економіку. День. 1 липня 2016. URL: https://day.kyiv.ua/uk/article/podorozhi/bilbao-muzey-guggenhayma (дата звернення: 15.01.2021).

18. Розумна О. П. Культурна дипломатія України: стан, проблеми, перспективи : аналітична доповідь. Київ : Національний інститут стратегічних досліджень, 2016. 53 c. URL: https://niss.gov.ua/sites/default/files/2016-09/ kultu_dypl-26841.pdf (дата звернення: 01.01.2021). 
19. Сич О. А. Використання коштів ЄС для фінансування ревіталізації міст (досвід Польщі). Соціально-економічні проблеми сучасного періоду України. 2014. Вип. 4(108). C. 208-214. URL: https://financial.Inu.edu.ua/ wp-content/uploads/2015/10/sepspu_2014_4_26-1.pdf (дата звернення: 05.11.2020).

20. Сучасний сталий розвиток в сфрері культури: зарубіжний досвід для України : монографрія / Н. М. Драгомирецька та ін.; за заг. ред. Н. М. Драгомирецької. Одеса : ОРІДУ НАДУ, 2019. 238 с.

21. Фарінья К. Розвиток культурних та креативних індустрій в Україні. 2017. URL: https://www.culturepartnership.eu/upload/editor/2017/Research/Creative\%20Industries\%20Report\%20for\% 20Ukraine_UA.pdf (дата звернення: 26.12.2020).

22. Флорида Р. Креативный класс. Люди, которые создают будущее. Москва, 2016. 38 с. URL: https://monster-book.com/reader/16550 (дата звернення: 11.12.2020).

23. Шевцова А.О. Креативні стратегії розвитку міст: сутність поняття та підходи до його розуміння. Український географрічний журнал. 2014. № 2. С. 39-43. URL: https://ukrgeojournal.org.ua/sites/default/files/ UGJ_2014_2_39-43.pdf (дата звернення: 20.11.2020).

24. Шершньова О. Нормативно-правові засади розвитку туристичної діяльності в малих містах Рівненщини. Ефрективність державного управління: зб. наукових праць. 2008. Вип. 16/17. С. 187-193. URL: https://eprints.oa.edu.ua/230/1/Normatyvnyj.pdf (дата звернення: 23.12.2020).

25. Foord Jo. Strategies for creative industries: an international review. Creative Industries Journal. 2008. Vol. 1(2). P. 91-113. URL: http://citeseerx.ist.psu.edu/viewdoc/download?doi=10.1.1.463.1200\&rep=rep1\&type=pdf (дата звернення: 17.02.2021).

26. Howkins J. The Creative Economy. New York: The Penguin Press, 2001. 116 p.

27. Montgomery J. R. The new wealth of cities: city dynamics and the fifth wave. Aldershot: Ashgate, 2007. $437 \mathrm{p}$.

28. Newbigin J. The Creative Economy: An Introductory Guide. London : The British Council, 2010. 86 p.

29. Richards, G., Palmer, R. Why cities need to be eventful. Eventful cities: Cultural management and urban revitalisation / G. Richards, R. Palmer (Eds.). 2010. Pp. 1-37. DOI: https://doi.org/10.1016/b978-07506-6987-0.10001-0 (дата звернення: 05.01.2021).

30. Smith A. Events and urban regeneration. The strategic use of events to revitalise cities. New York; London : Routledge, 2012. 320 p.

31.Zukin S. Destination culture: How globalization makes all cities look the same. Inaugural Working Paper Series. Center for Urban and GlobalStudies at Trinity College. 2009. Vol. 1(1). Pp. 1-26.

\section{REFERENCES:}

1. Boiko-Boichuk O. V. (2020) Svitovi tendentsii rozvytku mist: mizhnarodnyi dosvid [World' trends in cities development: international experience]. Available at: http://academy.gov.ua/ej/ej6/txts/07bovmmd.htm (in Ukrainian)

2. Bourdieu P. (2002) Formy kapitala [Forms of Capital]. Ekonomycheskaia sotsyolohyia - Economic Sociology, T. 3(5). 60-74. Available at: www.ecsoc.msses.ru. (in Russian)

3. Davymuka S. A., Fedulova L. I. (2017) Kreatyvnyi sektor ekonomiky: dosvid ta napriamy rozbudovy [Creative Economy Sector: Experience and Development Directions]: monohrafiya [a monograp]. Lviv: Dolishniy Institute of Regional Research of NAS of Ukraine. (in Ukrainian)

4. Zhuk Yu. I. (2015) Kreatyvne misto: kontseptsiia ta perspektyvy yii vprovadzhennia v malykh mistakh Lvivskoi oblasti [Creative City: Concept and Prospects of its Implementation in Small Towns of Lviv Region]. In Okhorona dovkillia [Environmental Protection]: zbirnyk. naukovyh stateiX Vseukrainskykh naukovykh Taliivskykh chytan -A Collection of Scientific Articles of the XI All-Ukrainian Scientific Taliyiv Readings (Part 1, pp. 29-35). Kharkiv: Kharkivskyi natsionalnyi universytet imeni V. N. Karazina, Available at: https://www.researchgate.net/publication/312627732_Kreativne_misto_Koncepcia_ta_perspektivi_ii_vprovadzenna_v_malih_mistah_Lvivskoi_oblasti (in Ukrainian)

5. Zukin S. (2015) Kultury gorodov [Cultures of cities]. Available at: https://readli.net/chitat-online/?b=1012769\&pg=1 (in Russian)

6. Karasiova N. A. (2019) Dosvid rozvynenykh krain u sferi kreatyvnoi ekonomiky [Experience of Developed Countries in the Field of Creative Economy]. Biznes Inform - Business Inform, 10, 30-37. Available at: https://www.business-inform.net/article/?year=2019\&abstract=2019_10_0_30_37 (in Ukrainian)

7. Kyryziuk S. V. (2014) Mizhnarodni ta vitchyzniani tendentsii rozvytku kreatyvnoi ekonomiky [International and Domestic Trends in the Creative Economy Development]. Naukovyi visnyk Khersonskoho derzhavnoho universytetu. Ekonomichni nauky - Scientific Bulletin of Kherson State University. Economic sciences, vol. 6(1), 68-72. (in Ukrainian)

8. Landry Ch. (2006) Kreativnyi horod [The Creative City]. Moskow: Classika - XXI. (in Russian)

9. Mazurenko V. P., Kopiika D. V. (2018) Natsionalni ta hlobalni vymiry rozvytku kreatyvnoi ekonomiky [National and Global Measures of the Development of Creative Economy]. Molodyi vchenyi-A Young Scientist, 8, 200-205. (in Ukrainian) 
10. Misto knyh [The city of books]. Available at: https://studway.com.ua/misto-knig/ (in Ukrainian)

11. Mozheiko V. (2018) Horod. Spontannost kreatyvnykh prostranstv [City. The Spontaneity of Creative Spaces]. Belorusskye novosty - Belarusian News. Available at: https://naviny.online/article/20180202/1517552298-vadim-mozheyko-gorod-spontannost-kreativnyh-prostranstv (in Russian)

12. Onlain-dyskussyia «Horodskaia ekonomyia y optymyzatsyia: kak bolshyie dannyie sokhraniaiut resursy» [Online Discussion "Urban Economy and Optimization: How Big Data Conserves Resources"]. Available at: https://archsovet.msk.ru/article/sobytiya/onlayn-diskussiya-gorodskaya-ekonomiya-i-optimizaciya-kak-bol-shiedannye-sohranyayut-resursy (in Russian)

13. Pine B. J., Gilmore J. H. (2005) Ekonomyka vpechatlenyi. Rabota - eto teatr, a kazhdyi byznes - stsena [The Economy of Impressions. Work is Theater and Every Business a Stage]. Moskow: Williams. (in Russian)

14. Porter M. (1990) Mezhdunarodnaia konkurentsyia. Konkurentnyie preymushchestva stran [International Competition. Competitive Advantages of Countries]. Moskow: Alpina Dydjital. (in Russian)

15. Ozhho D. (2020) Pryklady y rezultaty vprovadzhennia innovatsii u mistakh svitu: chastyna 1 [Examples and Results of Innovation in Cities Around the World: part 1]. Available at: http://reformcenter.org.ua/innovations1 (in Ukrainian)

16.Zaichuk V. O. (ed.) (2014) Referatyvnyi ohliad yevropeiskoho prava (traven-cherven 2014 r.) [Abstract review of European law (May-June 2014)]. Kyiv: Instytut zakonodavstva Verkhovnoi Rady Ukrainy. Available at: http://instzak.rada.gov.ua/uploads/documents/31308.pdf (in Ukrainian)

17. Rychka Yu. (2016) Bilbao. Muzei Huhhenkhaima. Yak suchasne mystetstvo vriatuvalo ekonomiku [Bilbao. Guggenheim Museum. How modern art saved the economy]. Den - Day, 1 lyp. [1 Jul.]. Available at: https://day.kyiv.ua/ uk/article/podorozhi/bilbao-muzey-guggenhayma (in Ukrainian)

18. Rozumna O. P. (2016) Kulturna dyplomatiia Ukrainy: stan, problemy, perspektyvy: Analitychna dopovid [Cultural diplomacy of Ukraine: state, problems, prospects: Analytical report]. Kyiv: Natsionalnyi instytut stratehichnykh doslidzhen. Available at: https://niss.gov.ua/sites/default/files/2016-09/kultu_dypl-26841.pdf (in Ukrainian)

19. Sych O. A. (2014) Vykorystannia koshtiv YeS dlia finansuvannia revitalizatsii mist (dosvid Polshchi) [The use of EU funds to finance urban revitalization (Polish experience)]. Sotsialno-ekonomichni problemy suchasnoho periodu Ukrainy - Socio-economic problems of the modern period of Ukraine, issue 4 (108), 208-214. Available at: https://financial.Inu.edu.ua/wp-content/uploads/2015/10/sepspu_2014_4_26-1.pdf (in Ukrainian)

20. Drahomyretska N. M., Druzhynin S. S., Dumynska S. V., Zhylavska R. P., Kovalova Yu. V. (2019) Suchasnyi stalyi rozvytok v sferi kultury: zarubizhnyi dosvid dlia Ukrainy [Modern sustainable development in the field of culture: foreign experience for Ukraine]: monohrafiya [a monograp]. Odesa: ORIDU NADU. (in Ukrainian)

21. Farinia K. (2017) Rozvytok kulturnykh ta kreatyvnykh industrii v Ukraini [Development of cultural and creative industries in Ukraine]. Available at: https://www.culturepartnership.eu/upload/editor/2017/Research/Creative\%20 Industries\%20Report\%20for\%20Ukraine_U.pdf (in Ukrainian)

22. Florida R. (2016) Kreatyvnyi klass. Liudy, kotorye sozdaiut budushcheie [The Rise of The Creative Class. Revisited]. Moskow. Available at: https://monster-book.com/reader/16550 (in Russian)

23. Shevtsova A.O. (2014) Kreatyvni stratehii rozvytku mist: sutnist poniattia ta pidkhody do yoho rozuminnia [Crative strategies of urban development: the concept essence and approached to its understanding]. Ukrainskyi heohrafichnyi zhurnal - Ukrainian Geographical Journal, 2, 39-43. Available at: https://ukrgeojournal.org.ua/sites/ default/files/UGJ_2014_2_39-43.pdf (in Ukrainian)

24. Shershnova O. (2008) Normatyvno-pravovi zasady rozvytku turystychnoi diialnosti v malykh mistakh Rivnenshchyny [Normative and Legal Grounds of Tourism Developments in Small Towns of Rivne Area]. Efektyvnist derzhavnoho upravlinnia: zbirnyk naukovykh prats - Efficacy Public Administration: Collection of scientific works, 16/17, 187-193. Available at: https://eprints.oa.edu.ua/230/1/Normatyvnyj.pdf (in Ukrainian)

25. Foord Jo. (2008) Strategies for creative industries: an international review. Creative Industries Journal, 1(2), 91-113. Available at: http://citeseerx.ist.psu.edu/viewdoc/download?doi=10.1.1.463.1200\&rep=rep1\&type=pdf

26. Howkins J. (2001) The Creative Economy. New York: The Penguin Press.

27. Montgomery J. R. (2007) The new wealth of cities: city dynamics and the fifth wave. Aldershot: Ashgate.

28. Newbigin J. (2010) The Creative Economy: An Introductory Guide. London: The British Council.

29. Richards, G., \& Palmer, R. (2010). Why cities need to be eventful. In G. Richards, \& R. Palmer (Eds.), Eventful cities: Cultural management and urban revitalisation, pp. 1-37. Elsevier. Available at: https://doi.org/10.1016/ b978-0-7506-6987-0.10001-0

30. Smith A. (2012) Events and urban regeneration. The strategic use of events to revitalise cities. New York; London: Routledge.

31.Zukin S. (2009) Destination culture: How globalization makes all cities look the same. Inaugural Working Paper Series. Center for Urban and GlobalStudies at Trinity College, 1(1), 1-26. 